\title{
Introduction: the cooperative firm as an alternative to the capital-owned business enterprise
}

\section{INTRODUCTION}

The precondition for depriving capital of its power is allowing workers to manage firms (especially medium and large enterprises) on their own, viz. creating a system of cooperatives or democratically managed enterprises. As used in this book, the terms self-managed firm and producer cooperative are synonymous with the term democratically managed enterprise because a system composed of firms of this kind realises workplace democracy to the full. Although cooperatives may come in a variety of different organisational models, they have in common one main characteristic: the application of the cardinal rule of democracy dictating that decision powers are to be solely and entirely vested in the members (or partners) of the firm in line with the 'one head one vote' criterion. Other organisational characteristics are optional and should be selected with an eye to the need to ensure efficiency - as will be explained further on.

This introduction offers a broad outline of the principal organisational characteristics of our cooperative enterprises.

\section{THE TWO FACETS OF COOPERATION}

In a historical outline of the British cooperative movement, Beatrice Potter (better known as Beatrice Webb) highlighted a 'radical distinction' between the 'Creed of Universal Competition' shaping the strategies of capitalistic firms and the 'Co-operative Idea' as the basis of the newly established anti-capitalistic firms. The former, she explained, are governed by 'the biological law of the survival of the fittest through the struggle for existence', whereas the latter operate in line with a different 
biological law, the 'law of adaptation', which determines that 'the modification of structure is brought about by the modification of function' (Potter 1893, pp. 18-19). And as these biological laws are scientifically beyond question, she continued, anyone combating competition because of its emphasis on egoism and ruthlessness (with the consequential degradation of everyday life and adverse impact on character) simply cannot accept the idea that cooperators are simply motivated by a desire to make profits. But is this true?

Two major points are worth discussing in connection with the inception of cooperativism. One, a motivational factor, is the determination of its founders to combat what they perceived as the evils of capitalism. The man to whom the origins of socialism and cooperativism are usually traced, Robert Owen (1771-1858) (see, for instance, Potter 1893, p. 17), had first-hand knowledge of industrial life in Manchester, of the race for wealth triggered by the ongoing Industrial Revolution in his day and the ruthless treatment of workers at the hands of manufacturers. His firm conviction that inhumanity, greed and the disintegration of all ethical principles were bred by the factory system and by free competition led him to plan new models of societal organisation in an effort to do away with a system designed to generate profits through cut-throat competition. Originally, Owen set up 'unity and cooperation villages' for the sole purpose of providing jobs to the unemployed, but later on he came to look upon them as 'a means of world regeneration through which the whole world could speedily be emancipated from the competitive profit system' (Cole 1953, p. 105).

A major pioneer of cooperation and trade unionism was William Thompson, who advocated the establishment of unions as tools for cutting the profits of capitalists and furthering the gradual rise of cooperative firms intended to take the place of the existing system of capital-managed business enterprises. On the assumption that the cooperative mode of production was superior to capitalism, Thompson strove to set up producer cooperatives and to oust capital owners from production processes (see Thompson 1827).

In Italy, the development of cooperation was strongly advocated by the political activist Giuseppe Mazzini. The core idea behind Mazzini's approach was the need to free workers from the 'wage yoke', turn them into 'self-standing producers and allow them to appropriate the full value of the output produced by them'. From his perspective, the role of capital (described as the 'arbiter of a production system to which it is alien') was to be taken over by associated labour, viz. by associations 
of workers expected to ensure that 'their members would be given equal voting rights at elections of pro-tempore (i.e. revocable) managers' and would be paid profits commensurate with the quantity and quality of the work input contributed by each of them. This, he argued, would be 'the ideal revolution', since its effect would be to make labour 'the economic basis of human society' (Mazzini 1935, pp. 109, 132). Owen, Thompson and Mazzini looked upon cooperation as a viable alternative system to capitalism.

The second point to be discussed in connection with the rise of cooperativism is its descent from mutual aid societies, entities which were designed to provide a set of benefits, including health aid, to their members and were set up in Italy with some success in the mid-nineteenth century. Much like cooperatives, mutual aid societies were originally created in response to capitalist exploitation. Due to surges in unemployment caused by the introduction of machinery during the Industrial Revolution, the lifestyles of most people were changing dramatically, thus creating a need for solidarity and mutual aid as a shield against the competitive spirit, individualism and egotism of the entrepreneurial class. Along with aid to the sick and post-partum allowances for mothers, mutual aid societies granted their members death and unemployment benefits, inability and old-age pensions, as well as other kinds of aid.

The two factors characterising the cooperative movement from its inception were in part consistent and in part in contradiction with each other, in terms that the organisations advocated by Owen, Thompson and Mazzini, though doubtless anti-capitalistic in nature, pursued philanthropic aims which made them unsuited to supplant capital-managed business enterprises. Considering that human personality in general and the conduct of producers tends to be shaped by individualistic and egoistic drives, solidarity and mutualism must necessarily prove ineffectual when it comes to outperforming and gradually ousting capitalistic enterprises from the economy. In other words, a firm which is expected to operate at high levels of efficiency must necessarily leverage the individual profit motive 'until the ambit of men's altruism grows wider' and make 'an intense appeal to the money-making and money-loving instincts of individuals as the main motive force of the economic machine' (Keynes 1931, pp. 241, 245).

This same conclusion is implied in the argument of Riguzzi and Porcari $(1925$, p. 191) which runs that in any regime the success of a cooperative, much like that of a privately owned enterprise, is a function of its ability to carry on production in accordance with the laws 
governing economic activity and the cost minimisation principle. Any cooperative firm aiming to put capital-owned enterprises out of play within a free competition environment has to apply these rules with utmost consistency. This is its true raison d'être.

A cooperative, I repeat, is faced with two antithetical options: if it resolves to shape its business policies in line with philanthropic and mutualistic aims, it will have to content itself with eking out a precarious existence and narrowly staying afloat within a capitalistic system where profit-earning enterprise rules the day; otherwise, if it resolves to turn its business into a success story, help free society from the 'wage yoke' and allow producers to appropriate their respective work outputs, it will have no option but to leverage the profit motive.

\section{PRODUCER COOPERATIVES}

Thanks to the rise of the earliest producer cooperatives, which Mill held to change workers into 'their own capitalists' (Mill 1871, p. 739), a solution to the above-mentioned contradiction seemed to be at hand because these new firms could do without the intermediation of a person who organises production, takes all the associated risks and thereby acquires title to cash the surplus, i.e. the difference between cost and revenue. In a producer cooperative, production is run by the partners themselves and it is these that are consequently entitled to cash the surplus and apportion it among themselves. That is why Mill $(1871$, p. 744) remarked that the partners of a producer cooperative are 'in a relation to their work which would make it their principle and their interest - at present it is neither - to do the utmost, instead of the least possible, in exchange for their remuneration' and why Pantaleoni described cooperatives as business enterprises which pursue distinctively economic aims in line with economic criteria and whose partners, though partly committed to noble aims, are nevertheless motivated by egoism and the desire to make a profit (Pantaleoni 1898, p. 133).

If cooperatives are analysed in abstract terms and without regard to historical experience, they can be described as enterprises in which 'the factors of production are rewarded by dividing up in agreed proportions the actual output of their cooperative efforts' (Keynes 1979, p. 66) and whose partners act rationally if they work towards maximising corporate revenues in an effort to add to their personal earnings (because by so doing they will maximise both their own incomes and those of their 
fellow partners). Accordingly, both personal utility calculations and solidarity feelings are aspects of worker-controlled enterprises.

Vilfredo Pareto was the first economist to emphasise the contradictoriness of the aims of cooperation (though he mentioned different aspects from those discussed in this introduction). By a curious irony he wrote that cooperatives are thriving for reasons other than those that were expected to ensure their success (Pareto 1926, pp. 382-3). Originally established with the aim of putting an end to cut-throat inter-firm competition and promoting worker solidarity in its place, in actual fact their entry into the market produced the effect of adding fresh competitors to those already in existence.

In other words, Pareto thought that cooperatives were able to engage in and even stand up to competition just because they were barely distinguishable from capitalistic firms. While paying lip service to solidarity, he argued, they actually leveraged the profit motive no less than their rivals. From his perspective, those economists who opposed cooperation in his day were grossly mistaken because they were missing the opportunity to welcome the rise of firms capable of vying with capitalistic companies and were hence 'implicitly endorsing the need to retain the role of intermediaries' in production (Pareto 1926, p. 384).

\section{THE TRADITIONAL COOPERATIVE FIRM}

The earliest cooperatives that got off the ground in Britain, including the Rochdale Society of Equitable Pioneers (set up by Owen in 1844), were 'consumer cooperatives', i.e. firms founded by groups of consumers for the purpose of maximising not revenue, but other types of benefits for their partners. Consumer cooperatives are sales outlets which do without capitalistic intermediaries and are consequently in a position to market goods at prices below those charged by other firms. This poses a need to establish the aspects that consumer cooperatives have in common with other cooperative models.

Traditionally, cooperators themselves and legal scholars, though not economists, have defined cooperatives as social organisation structures in which groups of workers or consumers join together with the aim of combating capitalistic exploitation by running business activities for their own account in a variety of sectors of the economy. Specifically, a consumer cooperative is a retail outlet whose partners jointly purchase goods at wholesale prices for resale to their fellow partners and manage to undercut other retailers because the prices they charge do not include 
the profit margin that is usually cashed by capitalistic outlets. Self-build housing cooperatives are set up in order to implement affordable housing projects. The partners use pooled resources to purchase and develop a building lot, i.e. to construct homes at low costs because they neither include the surplus value of the developed site, nor the profit margin that would have accrued to an external capitalistic developer. Producer or worker cooperatives operate in a variety of industries. The working partners run their firms for their own account and appropriate the output of their work without paying out part of the residual to a capitalistic employer. The same principle applies to cooperative banks, cooperative insurance companies and other types of cooperative firms.

The unifying factor common to all cooperatives is the determination to do without an intermediary and zero the earning potential of capitalists. In overall terms, a cooperative is a business enterprise which sets out to generate not profits, but other kinds of benefits associated with the fact that no part of the surplus has to be paid out to a capital owner.

These characteristics go to underscore the anti-capitalistic essence of cooperative firms, i.e. entities which are set up by members of the subaltern classes in an effort to evade the law of profit, the basic criterion of a capitalistic society which enables capital owners to hire workers, pay them a fixed income and appropriate the surplus notwithstanding the fact that this was actually generated by the workers. From this traditional perspective, producers', workers', consumers' and housing cooperatives are anti-capitalistic entities because the business activities of the former two are managed by their partners on their own and for their own account and because the partners of the others have access to goods, services or homes without paying out a 'surplus' to third parties.

In recent years, this traditional view has been called into question by some economists who object that only producer cooperatives are run in a manner that turns the partners into their own capitalists and employers (and hence overturns the worker-employee opposition). In other cooperatives, they argue, the partners pay their shares in the firm's capital, but then use hired workers to build their homes or market the goods purchased and, in general, adopt operational procedures that do not cancel the distinction between employers and employees.

In line with this widely shared objection, in the recent economic literature cooperation theory is ever more frequently identified with the economic theory of worker-controlled enterprises and the latter are usually made to coincide with producer, rather than consumer, cooperatives. 


\section{WORKER-CONTROLLED ENTERPRISES}

At this point, it is necessary to provide a more comprehensive picture of the worker-controlled enterprise. As mentioned, real-world cooperatives come in a variety of different models, which include not only producer and consumer cooperatives, but also pure labour and mixed capital-labour cooperatives, firms with state-owned production means (the Yugoslav model) and privately or group-owned production means (the Western model), cooperatives employing hired labour and firms exclusively formed of worker-members, and so forth. Consequently, besides keeping producer cooperatives strictly distinct from consumer cooperatives, it is convenient to define specifics which are common to all worker-controlled enterprises. Above all, it is necessary to clarify if the term worker-controlled enterprise is synonymous with producer cooperative and decide if cooperatives are to be distinguished from self-managed firms.

As the crucial distinction is clearly between publicly and privately owned production means, one might be tempted to conclude that a cooperative is a worker-controlled enterprise with privately owned production means and that a self-managed system is a system of worker-controlled enterprises with publicly owned production means. In fact, today this distinction is held to restrict both the notion of cooperative and that of worker-controlled enterprise (since the term cooperative designates a variety of different firm models and the worker-controlled enterprises discussed in the current literature are often privately owned).

Major cues are offered by Sertel, who holds that the basic characteristic of a workers' enterprise is the double status of its members as partners and workers. In other words, in Sertel's approach, a firm is defined as a workers' enterprise if its workforce is solely formed of its partners and, by contrast, as a capitalistic enterprise when it is not; that is to say, when none of its partners work for the firm and none of its workers are, at the same time, partners of the firm (see Sertel 1982, p. 13). Although Sertel's 'radical distinction' between workers' and capital-owned enterprises just covers borderline cases, it offers an excellent opportunity for analysing the specific characteristics of a cooperative firm exactly because it reflects extreme and purely ideal cases. Whereas the core factor behind Sertel's definition appears to be the ownership issue (the 'workers' enterprise' is owned by those working for it), the preferential focus of mainstream economists is on the management issue, and this explains 
why they define producer cooperatives as worker-controlled enterprises regardless of whether they are owned by the workers, the state or private individuals.

According to Vanek, the highest authority on this area, the main distinction within the category of producer cooperatives is not between publicly versus privately owned firms, but between firms which remunerate capital separately from labour (which he terms LMFs) and those which apportion all their revenues among their workers (specifically those who were engaged in production over the reference period) and do not pay out any part thereof to capital owners as such (WMFs) (see Vanek 1971a, 1971b).

At this point, we will focus simultaneously on Sertel's and Vanek's apparently antithetical stances and establish if, and to what extent, they can be reconciled. Although we do rate Vanek's as the basic distinction (the working modes of a firm segregating capital incomes from labour incomes differ greatly from those of firms that do not distinguish between these two income categories), on closer analysis there is evidence that the ownership issue is no less crucial to Vanek's distinction than it is to Sertel's because - in somewhat simplified terms - from the different investment funding practices of these firm models it follows that the LMF's capital goods are, for the most part, publicly owned while those of a WMF are usually the joint property of the partners.

And although this finding does not take us to the true heart of the matter, at this point it is possible to draw the provisional conclusion that a cooperative is a firm which is run by the workers themselves and may indifferently use privately or publicly owned capital goods and that a cooperative firm with publicly owned production means is tantamount to a self-managed firm.

In point of fact, even theorists who accept this definition of the cooperative firm tend to approach cooperation from diverging perspectives shaped by different cultural backgrounds. If they categorise the production means of a cooperative as the property of the workers' collective, they think of cooperation economics as the third, or group property sector, which operates alongside those of privately and publicly owned firms (see Jay 1980). If they hold a more modern view suggested by the approaches of Ward and Vanek, they tend to conceive of the capital goods of a cooperative as either owned by the workers' collective or the state (including public agencies) and to define a cooperative economy with publicly owned cooperatives as a system of self-managed firms; that is to say, as market socialism. 


\section{MILL'S AND MARSHALL'S APPROACHES TO COOPERATION}

Pareto's polemical description of coeval economists as enemies of producer cooperatives (see above) was just aimed at some mainstream scholars who did not see any viable alternatives to capital-owned enterprises. In fact, just a few years had elapsed since the time when economic scholars of renown greatly praised the cooperative movement. As mentioned above, Owen, Thompson and Mazzini looked upon cooperation as a viable alternative system to capitalism, and there are numerous other economists of considerable stature that do not fit within Pareto's description.

Among them was John Stuart Mill, whose critical attitude towards the typical capitalistic worldview is clearly revealed by the following quote:

I confess I am not charmed with the ideal of life held out by those who think that the normal state of human beings is that of struggling to get on; that the trampling, crushing, elbowing, and treading on each other's heels, which form the existing type of social life, are the most desirable lot of humankind, or anything but the disagreeable symptoms of one of the phases of industrial progress. (Mill 1871, p. 20)

Mill looked upon work in association as the beachhead for the emancipation of the working class.

The civilising and improving influences of association and the efficiency and economy of production on a large scale may be obtained without dividing the producers into two parties with hostile interests and feelings, the many who do the work being mere servants under the command of the one who supplies the funds, and having no interest of their own in the enterprise except to earn their wages with as little labour as possible (Mill 1871, p. 722).

More precisely, from Mill's perspective, one major advantage of production in association was to transform human life 'from a conflict of classes struggling for opposite interests, to a friendly rivalry in the pursuit of a good common to all' (1871, p. 744).

Authoritative supporters of the cooperative movement include Marshall, who claimed that cooperation 'does rest in a great measure on ethical motives' (Marshall 1890, p. 292), combines 'high inspirations with calm and strenuous action' and has the 'direct aim to improve the 
quality of man himself' more than any other movement with which it has points of affinity (Marshall 1925, p. 227).

Marshall is arguably the greatest and best known of all mainstream economists and his comments on cooperatives are not necessarily based on a misunderstanding of their true nature or his failure to realise that the partners of cooperative firms act in their personal interests.

All this said, Marshall's emphasis on the commitment of cooperators to collective aims can probably be explained if we bear in mind that the partners of a cooperative who strive to maximise corporate revenues simultaneously scale up the incomes of all their fellow partners.

Marx himself praised cooperatives on several occasions and thought of the rise of producer cooperatives as a new mode of production capable of leading to the demise of capitalism.

\section{THE WANING CONSENSUS ON COOPERATION AMONG ECONOMISTS}

From the late nineteenth century onwards, economic theorists became less and less supportive of cooperation and some of them turned their back on it (as mentioned by Pareto). In Italy, the heyday of cooperation lasted longer than elsewhere and reached a peak under the premiership of Giolitti. After the Paris Commune of 1870, Marx himself began to lose faith in a movement which he had rated as a potential new mode of production. In part, this change of focus among economists was caused by a downward trend in the overall performance levels of these firms and by the feeling that the movement had failed to live up to their expectations. Bernstein, for example, was convinced that producer cooperatives had no future and recommended establishing consumer cooperatives only.

A case apart was Italy during the premiership of Giolitti, when Gramsci's writings and the events of the so-called 'red biennium' induced the cooperative movement to propose the conversion of Fiat works into a cooperative enterprise.

In part, the decline of the cooperative movement in the early 1870 s was caused by the rise of marginalism, a view of economics which revolutionised economic thinking and remained extremely critical of cooperation for many years. In many respects, marginalism can be described as a 'mechanical' theory because it postulates the existence of 'natural' economic equilibria which the spokesmen for this current of thought rate as bound to last forever. Utility calculus, the main focus point of marginalism, would suggest that provided a social system is organised 
in line with rational criteria the wage rates prevailing in it will always be commensurate with the marginal productivity of labour and that the same rule also applies to capital and to 'land'. The theory of general economic equilibrium which was fleshed out by marginalist thinkers (Walras and Pareto) leads up to 'Pareto optimality'; that is to say, to the assumption that in perfect competition markets there is always one and only one equilibrium point which vouchsafes maximum social welfare and that this point is unrelated to the institutional context. This means that the equilibrium point of an efficient market economy is always the same, irrespective of whether the enterprises operating within it are capital- or worker-owned. In other words, in a perfectly competitive market economy it makes no difference if it is capital that hires labour or vice versa (i.e. if it is labour that manages enterprises with loan capital).

Marginalist theory is at the heart of an 1898 paper in which Matteo Pantaleoni stated that both consumer and producer cooperatives are profit-making entities and, as such, 'adopt business strategies geared towards making money ... engage in the production of goods with the aim of cutting costs as much as possible and strive to generate benefits for all their partners' (Pantaleoni 1898, pp. 132-3).

For the purposes of this book, the most interesting implication of the opinion of Pantaleoni is that aspects ostensibly specific to cooperatives only are actually common to all business enterprises. Insofar as it is true that 'each cooperator is exclusively concerned with making utility calculations' and that 'individuals engage in business for the sole purpose of gaining personal benefit', it follows that, given the absence of aspects specific to cooperatives only, 'the price formation model that would arise if the principles of cooperation were consistently and universally applied would by no means differ from the price formation model arising in free competition contexts whose operators are not committed to any of such principle' (Pantaleoni 1898, p. 142).

In support of his arguments, Pantaleoni examined a number of principles and characteristics which were traditionally ascribed to cooperative firms in order to argue that 'the so-called cooperative principles can only act themselves out in contexts characterised by the simultaneous existence of non-cooperative enterprises'. His ultimate conclusion was that the assumed specifics of cooperative firms were actually 'aspects common to any other enterprise operating for profit' and that, consequently, the rationale behind cooperation 'was not an autonomous principle' (Pantaleoni 1898, p. 145). All this is clear evidence that 
marginalism was a major cause of the waning consensus on cooperation among economists.

\section{THE CONTRIBUTION OF BENJAMIN WARD}

The first discordant note was struck as late as 1958, when the American economist Benjamin Ward challenged Pantaleoni's opinions by arguing that capitalistic enterprises differed from cooperatives or self-managed firms because the former strove to maximise profits (or the rate of return on their investment), while the latter were concerned with maximising the average income levels of their workers. The core point of Ward's argument became the starting point for the author's theory of the behaviour of firms and his 1958 paper is now rated as a classic. The publication of Ward's paper led to the emergence of the economic theory of producer cooperatives, a new research field founded on the assumption that cooperatives are enterprises aiming to maximise the average incomes of their workers. Considering the pace at which the scholarly literature on producer cooperatives has been expanding over the past decades, today it is possible to argue that the contemporary theory of the firm falls into two broad subdivisions: the traditional theory of the (capitalistic) enterprise as a firm model concerned with maximising its profits and the theory of the cooperative (or self-managed) firm founded on the assumption that this firm model strives to maximise the average income of its labourers.

This means that the criticisms of Pantaleoni and other neoclassical economists have been dismantled without being explicitly rebutted. In Ward's approach, cooperatives differ from capital-managed enterprises because they adopt a behavioural principle other than profit maximisation, but from 1958 onwards researchers highlighted and discussed an increasing number of differences between these two firm models.

The partners of a cooperative can be categorised as 'rational egoists' because they are aware that any efforts to maximise the firm's total revenues will also drive up their own incomes. Accordingly, the motivational factor behind their efforts to boost the firm's average or total profits is not altruism, but a rational form of egoism which strips the cooperative movement of its utopian overtones and goes to refute the claim that cooperation requires of necessity 'the birth of a new man'.

Taking the cue from Ward's 1958 paper, Jaroslav Vanek made a pivotal contribution to the emerging theory of producer cooperatives by introducing the distinction between cooperatives that segregate labour incomes from capital incomes (LMFs) and cooperatives which 
self-finance their investments, do not keep distinct these two types of income and pay out to their partners mixed capital and wage labour incomes (WMFs) (see Vanek 1971a, 1971b).

\section{THE MODERN ECONOMIC THEORY OF PRODUCER COOPERATIVES}

The above reflections lead to the conclusion that the cooperative of which we speak is a worker-controlled (i.e. self-managed and democratic) enterprise whose residual (the difference between revenues and costs) is cashed by the worker-members. Economists' co-ops carry on business in the market with the aim of maximising the incomes of their members and are not subject to any restrictions, except for the ban on taking on hired workers (eventually, in numbers exceeding pre-fixed limits). In short, the 'pure' LMF type or economists' co-op can be said to reverse the relation between capital and labour specific to capitalism. Indeed, whereas the capitalistic investor-owned enterprise strives to maximise the income accruing to capital owners by taking on hired workers, paying out to them a fixed income (wage or salary) and appropriating the residual, in economists' co-ops it is the workers that operate in their own and their fellow partners' interests by operating with loan capital, paying capital providers a fixed income (interest) and keeping the surplus for themselves (see, e.g. Srinivasan and Phansalkar 2003, p. 366).

The capital-labour relation specific to capitalism is overturned because in the cooperative or self-managed firm the organisational model enabling capitalists to exercise control over labour is replaced by a model which transfers control powers to the workers. In the face of the ever tighter control that is being exercised by capitalists over their enterprises in consequence of rapid surges in the sheer amount of capital goods, the need to reverse the existing capital-labour relation is becoming ever more urgent. In a world which is characterised by escalating capital control, the time has come for workers to wrest themselves free from the resulting oppression.

Although economists' co-ops are not committed to the mutuality principle that legal theorists rate as essential, they operate in accordance with the cooperative principles originally laid down by Owen, Thompson and Mazzini and can therefore be rated not only as genuine cooperative firms, but as even more genuine than the jurists' co-ops that are currently operating in Italy and elsewhere. Like the earliest cooperatives, they are anti-capitalistic entities not because they reject the prospect of 
co-existing with capital-owned enterprises, but because thanks to the reversal of the capital-labour relation they are the opposite of capitalistic enterprises. And as they vest corporate decision powers in all their partners (and consequently substitute the 'one head, one vote' criterion for the 'one share, one vote' principle governing the exercise of corporate power in capital-owned enterprises), they can also be described as 'democratic firms'.

Moreover, due to the above-mentioned anti-capitalistic essence and the tendency to upturn the existing capital-labour relation, the cooperative can also be described as a 'socialist' entity. In a valuable historical outline of the cooperative movement Beatrice Webb offered an analysis of different cooperative firm models and drew the following conclusion:

we should miss the national significance of the Co-operative movement, the spiritual meaning of the future grocer's shop, if we failed to realize that all these manifold forms of democratic association, with their various ways and different methods, had one aim and one motive - the same aim and the same motive, curiously enough, described as the cause of the mediaeval communes: the desire on the part of a majority to regulate and to limit the exploitation of their labour by a powerful and skilled minority. (Potter 1893, p. 39)

Let me add that the description of economists' co-ops as genuine cooperative firms is confirmed by a distinction that cooperators and legal theorists tend to draw between capitalistic and cooperative firms. Whereas Owen and other early theorists held that cooperatives had to self-finance all their investments, modern economists tend to maintain, with Vanek (1971a, 1971b), that they should rather opt for loan capital financing.

The implicit return of modern economists to the very origins of the cooperative movement and their endorsement of cooperation as an alternative to capitalistic enterprises are evidence that it is difficult to agree with Sapelli when he argues that the current debate on cooperation is unlikely to take us very far, that it is not by chance that this debate has mainly been involving economists of neoclassical extraction for several years now (specifically about 20 years or so), or that 'due to the "sleep of reason" benumbing the minds of "older" cooperation theorists the reductionist findings emerging from their research have been allowed to circulate freely to the point of becoming the received view'. The latest literature, he adds, offers a chain of laughable, if not embarrassing research propositions. Among these are the tentative application of economic analysis methods to the study of producer cooperatives, notwithstanding the fact that these are economic organisations only in part. 
In Sapelli's opinion, they are the materialisation of the desire of people to protect themselves and their values by working in association (and not based on individual contracts) and 'can be better understood against the background of the approach of Durkheim, rather than that of Jevons, of Mauss rather than Williamson' (Sapelli 2006, pp. 11-12).

Although there is little denying that until some time ago neoclassical economic speculation tended to proceed 'by way of reduction' and was marred by 'economistic overtones', it is fair to say that today things stand differently, which means that this criticism is probably applicable to earlier neoclassical scholars such as Pantaleoni, but much less so to the work of Meade or Sen in the field of cooperation theory. From my perspective, Sapelli's line of reasoning should be reversed, in terms that today the true reductionists are all those cooperators and legal theorists who categorise cooperation as the 'third sector' of the economy. In contrast, the cooperative firm system upheld in this book offers a rich array of non-economic benefits that justify its classification as a 'genuinely socialist' entity.

Lastly, it is a fact that modern professional economists are barely familiar with the modern economic theory of producer cooperatives. This means that cooperation theorists have probably failed to turn the spotlight on the true plus point of such a firm system: its potential for realising economic democracy. Consequently, they argue that the plan to establish 'worker control' has strangely 'antiquated' overtones that call to mind conditions and political movements of the past.

\section{NOTES}

1. Potter suggested that Owen himself was fully aware of this contradiction (see Potter 1893, pp. 24-8).

2 Marx held that workers should 'embark on co-operative production rather than on co-operative stores', because the latter 'touch only the surface of the economic system' and only the latter are suited to 'strike at its foundations' (Marx 1866, p. 190) - an argument to which Bernstein took exception (see Bernstein 1899, pp. 149-59).

3. Mill's theoretical approach to cooperation is analysed in depth by Pesciarelli (1981, ch. 6) and Zanotti (2020).

4. Here, Pantaleoni seems to adopt the viewpoint of an economist in rewording the well-known saying of Hobbes that cooperation is not conceivable between individuals concerned with maximising their personal interests, i.e. between people he categorises as 'rational egoists'.

5. Potter described democracy as 'the distinct characteristic of the movement since its inception' (Potter 1893, p. 63) and cooperation and legal theorists 
today concordantly hold that social functions of cooperation are exercised in accordance with the principle of economic democracy (see, inter alia, Galgano 1982, p. 81). As argued by Galgano, cooperatives differ from capitalistic enterprises because they apply the 'one head, one vote' principle and, hence, 'repudiate the plutocratic principle based on which power and control are vested in the wealthy at a scale which is proportional to the amount of wealth owned by an individual' (Galgano 1974, p. 174). 